\title{
Safety Testing of AGR-2 UCO Compacts $5-2-2,2-2-2$, and 5-4-1
}

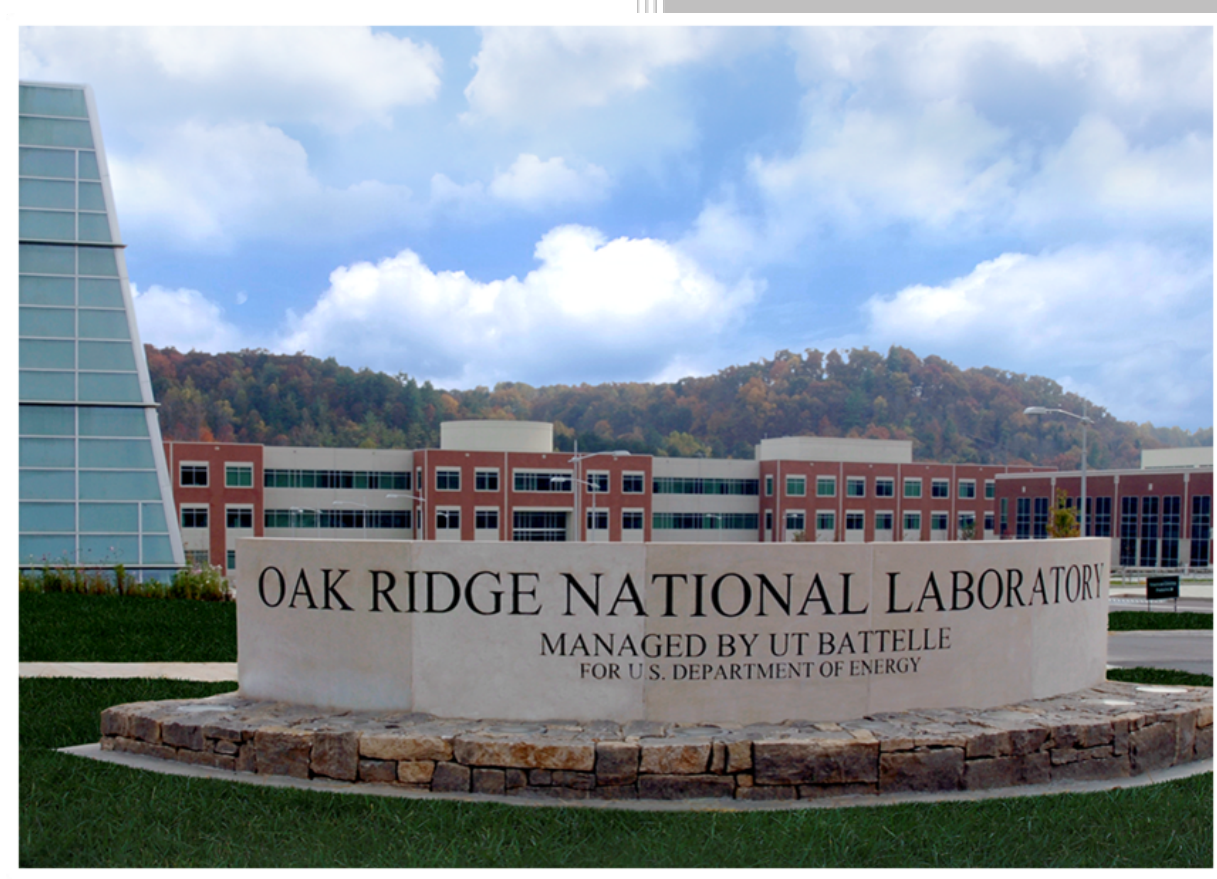

Approved for public release. Distribution is unlimited.

John D. Hunn

Robert N. Morris

Charles A. Baldwin

Fred C. Montgomery

October 2016 


\title{
DOCUMENT AVAILABILITY
}

Reports produced after January 1, 1996, are generally available free via US Department of Energy (DOE) SciTech Connect.

Website http://www.osti.gov/scitech/

Reports produced before January 1, 1996, may be purchased by members of the public from the following source:

\author{
National Technical Information Service \\ 5285 Port Royal Road \\ Springfield, VA 22161 \\ Telephone 703-605-6000 (1-800-553-6847) \\ TDD 703-487-4639 \\ Fax 703-605-6900 \\ E-mail info@ntis.gov \\ Website http://www.ntis.gov/help/ordermethods.aspx
}

Reports are available to DOE employees, DOE contractors, Energy Technology Data Exchange representatives, and International Nuclear Information System representatives from the following source:

Office of Scientific and Technical Information

PO Box 62

Oak Ridge, TN 37831

Telephone 865-576-8401

Fax 865-576-5728

E-mail reports@osti.gov

Website http://www.osti.gov/contact.html

This report was prepared as an account of work sponsored by an agency of the United States Government. Neither the United States Government nor any agency thereof, nor any of their employees, makes any warranty, express or implied, or assumes any legal liability or responsibility for the accuracy, completeness, or usefulness of any information, apparatus, product, or process disclosed, or represents that its use would not infringe privately owned rights. Reference herein to any specific commercial product, process, or service by trade name, trademark, manufacturer, or otherwise, does not necessarily constitute or imply its endorsement, recommendation, or favoring by the United States Government or any agency thereof. The views and opinions of authors expressed herein do not necessarily state or reflect those of the United States Government or any agency thereof. 


\title{
SAFETY TESTING OF AGR-2 UCO COMPACTS 5-2-2, 2-2-2, AND 5-4-1
}

John D. Hunn

Robert N. Morris

Charles A. Baldwin

Fred C. Montgomery

Revision 1

\author{
Work sponsored by \\ US DEPARTMENT OF ENERGY \\ Office of Nuclear Energy - Advanced Reactor Technologies \\ under the \\ Advanced Gas Reactor Fuel Development and Qualification Program
}

Prepared by

OAK RIDGE NATIONAL LABORATORY

Oak Ridge, TN 37831-6283

managed by

UT-BATTELLE, LLC

for the

US DEPARTMENT OF ENERGY

under contract DE-AC05-00OR22725 



\section{CONTENTS}

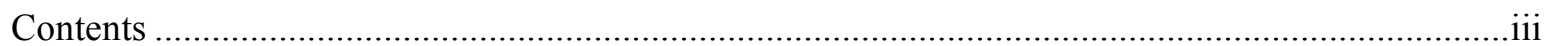

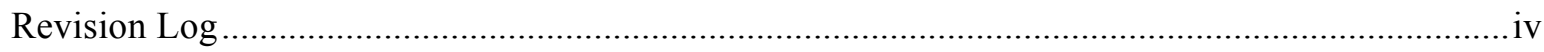

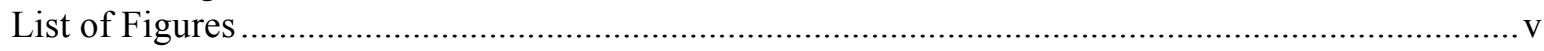

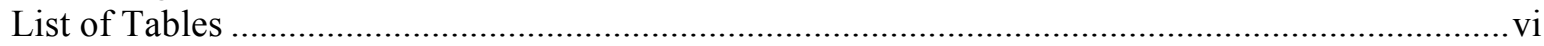

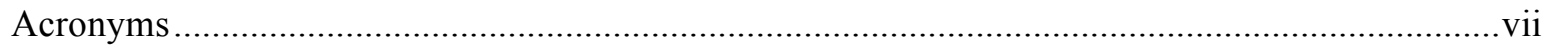

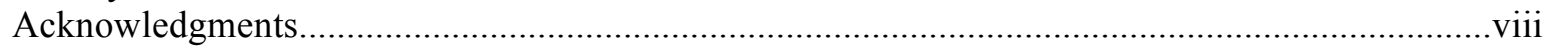

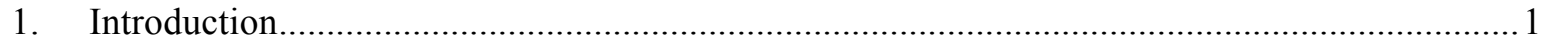

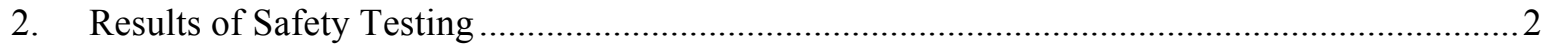

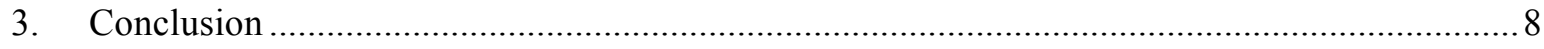

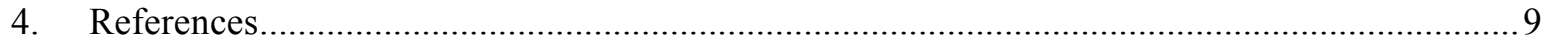




\section{REVISION LOG}

\begin{tabular}{cccc}
\hline Revision & Date & Affected Pages & Revision Description \\
\hline 0 & $08 / 31 / 16$ & All & Initial issue \\
1 & $10 / 22 / 16$ & 9 & Corrected the Demkowicz et al. 2015b reference
\end{tabular}




\section{LIST OF FIGURES}

1. Release of fission products from Compact 5-2-2 during safety testing to $1600^{\circ} \mathrm{C}$.....................

2. Release of fission products from Compact 2-2-2 during safety testing to $1600^{\circ} \mathrm{C}$. .....................

3. Release of fission products from Compact 5-4-1 during safety testing to $1800^{\circ} \mathrm{C}$. ....................

4. Rate of fission product release from Compact 5-2-2 during safety testing to $1600^{\circ} \mathrm{C} \ldots \ldots \ldots \ldots \ldots . . .6$

5. Rate of fission product release from Compact 2-2-2 during safety testing to $1600^{\circ} \mathrm{C}$...............6

6. Rate of fission product release from Compact 5-4-1 during safety testing to $1600^{\circ} \mathrm{C} \ldots \ldots \ldots \ldots \ldots . . . . .7$ 


\section{LIST OF TABLES}

1. Irradiation conditions for AGR-2 UCO Compacts 5-2-2, 2-2-2, and 5-4-1 ............................2

2. Radioactive isotope distribution on furnace internal components after the

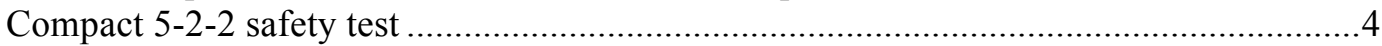

3. Radioactive isotope distribution on furnace internal components after the

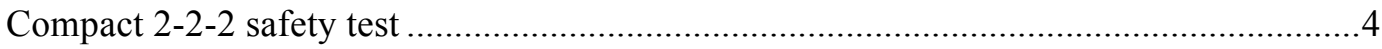

4. Radioactive isotope distribution on furnace internal components after the

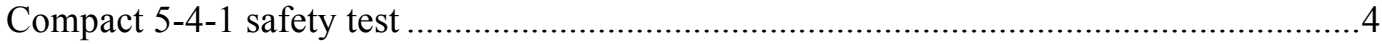

5. Cumulative releases of radioactive isotopes from AGR-2 UCO TRISO safety tests..................5 


\section{ACRONYMS}

AGR

AGR-1

AGR-2

BWXT

CCCTF

$\mathrm{CO}$

DLBL

FACS

FIMA

HTGR

IFEL

IMGA

INL

OPyC

ORNL

PIE

$\mathrm{SiC}$

TAVA

TRISO

UCO

$\mathrm{UO} 2$
Advanced Gas Reactor (Fuel Development and Qualification Program)

First AGR program irradiation experiment

Second AGR program irradiation experiment

BWX Technologies

Core Conduction Cooldown Test Facility

Carbon monoxide

Deconsolidation leach-burn-leach

Fuel Accident Condition Simulator

Fissions per initial metal atom

High Temperature Gas-cooled Reactor

Irradiated Fuels Examination Laboratory (hot cells)

Irradiated Microsphere Gamma Analyzer

Idaho National Laboratory

Outer pyrolytic carbon (TRISO layer)

Oak Ridge National Laboratory

Post-irradiation examination

Silicon carbide (TRISO layer)

Time-averaged/volume-averaged temperature

Tristructural-isotropic (coated particles)

Uranium carbide/uranium oxide mixture (fuel kernels)

Uranium dioxide (fuel kernels) 


\section{ACKNOWLEDGMENTS}

This work was sponsored by the U.S. Department of Energy, Office of Nuclear Energy, through the Idaho National Laboratory Advanced Reactor Technologies Technology Development Office as part of the Advanced Gas Reactor Fuel Development and Qualification Program. Analysis of leach solutions and Core Conduction Cooldown Test Facility furnace components was provided by the Oak Ridge National Laboratory Nuclear Analytical Chemistry \& Isotopics Laboratory. Hot cell activities were supported by the staff of the Oak Ridge National Laboratory Irradiated Fuels Examination Laboratory. 


\section{INTRODUCTION}

Post-irradiation examination (PIE) is being performed on tristructural-isotropic (TRISO) coated-particle fuel compacts from the Advanced Gas Reactor (AGR) Fuel Development and Qualification Program second irradiation experiment (AGR-2) [Collin 2014]. This effort builds upon the understanding acquired throughout the AGR-1 PIE campaign [Demkowicz et al. 2015a] and is establishing a database for the different AGR-2 fuel designs.

The AGR-2 irradiation experiment included TRISO fuel particles coated at BWX Technologies (BWXT) with a 150 -mm-diameter engineering-scale coater. Two coating batches were tested in the AGR-2 irradiation experiment. Batch 93085 had 508- $\mu$ m-diameter uranium dioxide $\left(\mathrm{UO}_{2}\right)$ kernels. Batch 93073 had 427 - $\mu$ m-diameter UCO kernels, which is a kernel design where some of the uranium oxide is converted to uranium carbide during fabrication to provide a getter for oxygen liberated during fission and limit CO production. Fabrication and property data for the AGR-2 coating batches have been compiled [Barnes and Marshall 2009] and compared to AGR-1 [Phillips, Barnes, and Hunn 2010]. The AGR-2 TRISO coatings were most like the AGR-1 Variant 3 TRISO deposited in the 50-mm-diameter ORNL lab-scale coater [Hunn and Lowden 2006]. In both cases argon-dilution of the hydrogen and methyltrichlorosilane coating gas mixture employed to deposit the $\mathrm{SiC}$ was used to produce a finer-grain, more equiaxed SiC microstructure [Lowden 2006; Gerczak et al. 2016]. In addition to the fact that AGR-1 fuel had smaller, 350- $\mu$ m-diameter UCO kernels, notable differences in the TRISO particle properties included the pyrocarbon anisotropy, which was slightly higher in the particles coated in the engineeringscale coater, and the exposed kernel defect fraction, which was higher for AGR-2 fuel due to the detected presence of particles with impact damage introduced during TRISO particle handling [Hunn 2010].

Irradiation test compacts containing AGR-2 fuel particles were compacted at ORNL with the same resinated-graphite blend used to make AGR-1 compacts and a modified pressing process that utilized a die heated to $65^{\circ} \mathrm{C}$ and a new computer-controlled servo-press. Two compact lots were produced and qualified for the AGR-2 irradiation test: lot LEU09-OP2-Z contained the UCO TRISO particles [Hunn, Montgomery, and Pappano 2010a] and lot LEU11-OP2-Z contained the $\mathrm{UO}_{2}$ fuel [Hunn, Montgomery, and Pappano 2010b]. Compared to the AGR-1 compacts, which were compacted at room temperature using a manual press, the modified AGR-2 compacting process produced compacts with reduced variability in length and higher matrix density (1.6-1.7 g/cc for AGR-2 versus 1.2-1.3 g/cc for AGR-1). Compilations of the properties data for the particles and compacts are available in pre-irradiation characterization summary reports for the AGR-1 [Hunn, Savage, and Silva 2012] and AGR-2 [Hunn, Savage, and Silva 2010] fuel composites.

The AGR-2 Post-Irradiation Examination Plan [Demkowicz 2013] includes safety testing of the irradiated compacts in the Oak Ridge National Laboratory (ORNL) Core Conduction Cooldown Test Facility (CCCTF) to evaluate the effect of elevated temperature on fuel microstructure, individual particle coating failure, and overall fission product ${ }^{*}$ retention. The safety tests involve heating compacts in flowing helium to maximum temperatures of $1600-1800^{\circ} \mathrm{C}$ and holding at these test temperatures for approximately $300 \mathrm{~h}$. The standard test temperature of $1600^{\circ} \mathrm{C}$ is the expected maximum temperature during a high-temperature gas-cooled reactor (HTGR) depressurization conduction-cooldown event, while $1700^{\circ} \mathrm{C}$ and $1800^{\circ} \mathrm{C}$ tests explore the safety margin and provide additional data on mechanisms for particle coating failure, fission product diffusion, and other fission product interactions with the TRISO coatings. The first two AGR-2 safety tests were performed on AGR-2 $\mathrm{UO}_{2}$ Compacts 3-3-2 and 3-4-2; both were heated to $1600^{\circ} \mathrm{C}$ in flowing helium for $300 \mathrm{~h}$ and results were summarized in a previous report

\footnotetext{
"In this report, the term "fission product" is used in a general sense to refer to all the post-fission isotopes remaining at the end of the irradiation test. These include: isotopes directly generated by the fission process, isotopes generated by neutron activation, isotopes generated by radioactive decay, and residual uranium.
} 
[Hunn et al. 2015a]. These $\mathrm{UO}_{2}$ Compacts both exhibited multiple particle failure at $1600^{\circ} \mathrm{C}$ due to $\mathrm{CO}$ corrosion, which is in sharp contrast to the performance of the UCO compacts that have been safety tested thus far [Morris et al. 2016].

In this report, results of safety testing on three AGR-2 UCO compacts are reported. Compacts 5-2-2 and 2-2-2 were both safety tested at $1600^{\circ} \mathrm{C}$, while Compact 5-4-1 was safety tested at $1800^{\circ} \mathrm{C}$. Table 1 shows the calculated burnup in percent fissions per initial metal atom (FIMA), the fast neutron fluence (neutron energies $>0.18 \mathrm{MeV}$ ), and the average compact temperatures during irradiation. The irradiation doses for these compacts were similar, but Compact 2-2-2 was irradiated at a significantly higher temperature.

Table 1. Irradiation conditions for AGR-2 UCO Compacts 5-2-2, 2-2-2, and 5-4-1

\begin{tabular}{cccccc}
\hline Compact ID $^{a}$ & Fabrication ID $^{b}$ & Fuel Type & $\begin{array}{c}\text { Average Burnup } \\
(\% \text { FIMA })\end{array}$ & $\begin{array}{c}\text { Fast Fluence }^{c} \\
\left(\mathrm{n} / \mathrm{m}^{2}\right)\end{array}$ & $\begin{array}{c}\text { Temperature }^{\mathrm{d}} \\
\left({ }^{\circ} \mathrm{C}\right)\end{array}$ \\
\hline AGR-2 5-2-2 & LEU09-OP2-Z128 & UCO & 12.34 & $3.39 \times 10^{25}$ & 1141 \\
AGR-2 2-2-2 & LEU09-OP2-Z075 & UCO & 12.55 & $3.39 \times 10^{25}$ & 1287 \\
AGR-2 5-4-1 & LEU09-OP2-Z028 & UCO & 12.05 & $3.12 \times 10^{25}$ & 1071 \\
\hline
\end{tabular}

${ }^{a}$ The X-Y-Z compact identification (ID) convention denotes the location in the irradiation test train: Capsule-Level-Stack.

${ }^{b}$ Physical properties data for individual compacts are available and tabulated based on fabrication ID [Hunn, Montgomery, and Pappano 2010a, pages 60-69].

${ }^{c}$ Burnup [Sterbentz 2014, table 6] and fast fluence [Sterbentz 2014, table 12] are based on physics calculations.

${ }^{d}$ Time-averaged, volume-averaged (TAVA) irradiation temperature [Hawkes 2014, table 4] is based on thermal calculations.

Safety testing in the CCCTF furnace was accomplished with the same methods used for AGR-1 safety testing [Baldwin et al. 2012]. Compacts were placed in a graphite holder that positions the compact in the furnace and simulates the graphite that surrounds the compacts in a prismatic-block reactor. A watercooled deposition cup located near the top of the tantalum-lined furnace chamber collected vaporized metallic elements that escaped from the compact and surrounding graphite holder. Deposition cups were periodically removed and replaced with a new cup using a maximum exchange interval of $\sim 24 \mathrm{~h}$ and shorter exchange intervals for the first few cups removed after heating up to the test temperature. The cups were monitored with gamma spectrometry to track safety test progress, with particular emphasis on collected cesium inventory that would indicate SiC failure [Hunn et al. 2014a]. Gaseous fission products were collected from the helium sweep gas as it passed through a liquid-nitrogen-cooled trap that was monitored for ${ }^{85} \mathrm{Kr}$ because significant and rapid krypton release would indicate complete failure of a TRISO coating [Morris et al. 2014]. After completion of each safety test, additional analysis was performed to measure fission products on the deposition cups and other CCCTF furnace internals (graphite fuel holder, tantalum furnace liner, and tantalum gas inlet line). This allowed for the determination of an average deposition cup collection efficiency for each detected fission product, and this efficiency value was used to adjust the time-dependent deposition cup data to estimate the timedependent fission product release from the compact.

\section{RESULTS OF SAFETY TESTING}

Figure 1-Figure 3 summarize the overall estimated time-dependent fission product release from the safety tests. The plotted data points represent the measured amount of an isotope collected on a deposition cup divided by the calculated amount of that isotope expected to be present as a result of the irradiation test [Sterbentz 2014] and adjusted for the deposition cup collection efficiency by dividing by the cumulative fraction of that isotope collected on the cups throughout the test (Table 2-Table 4, Row 1). 


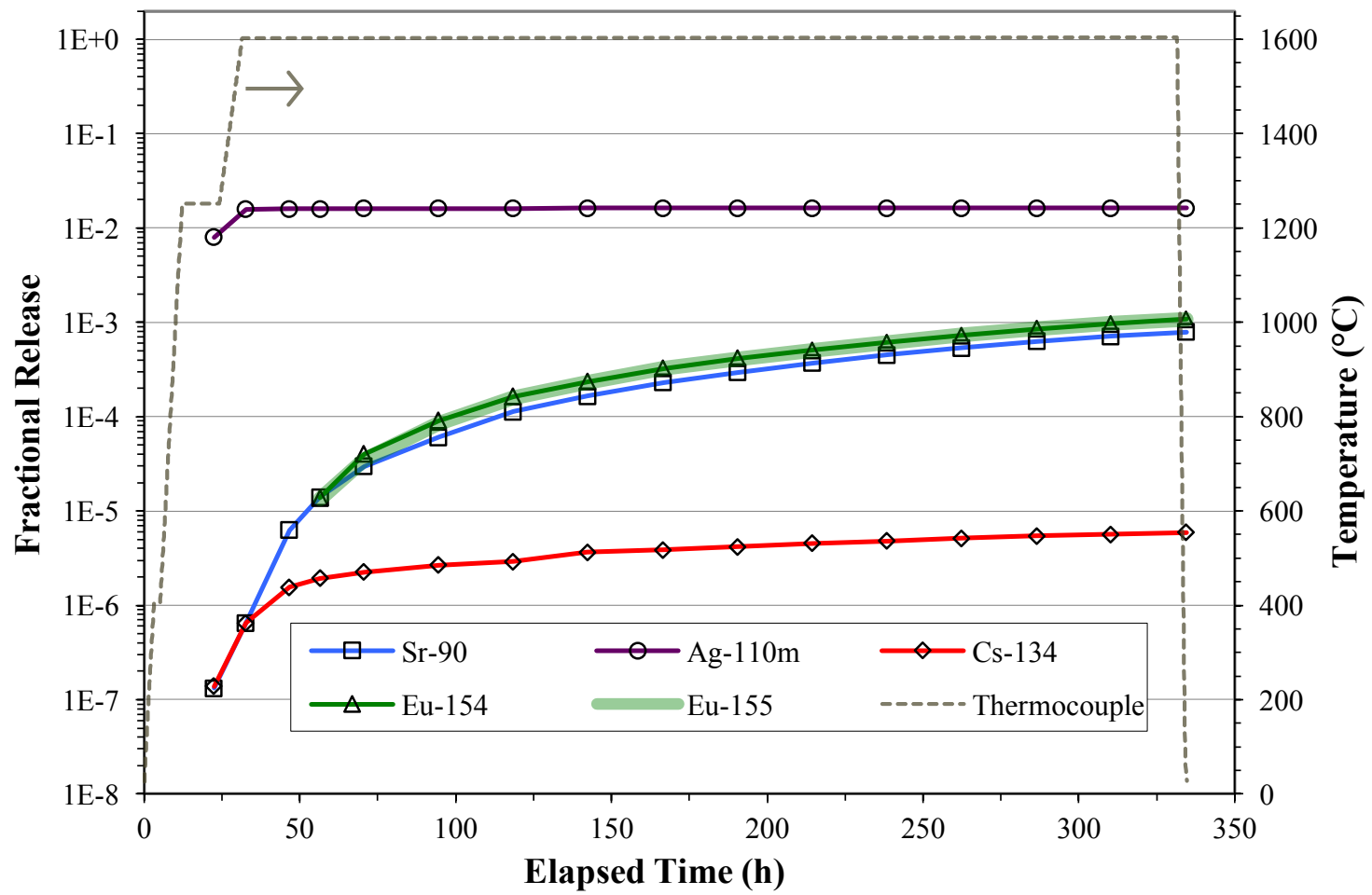

Figure 1. Release of fission products from Compact 5-2-2 during safety testing to $1600^{\circ} \mathrm{C}$.

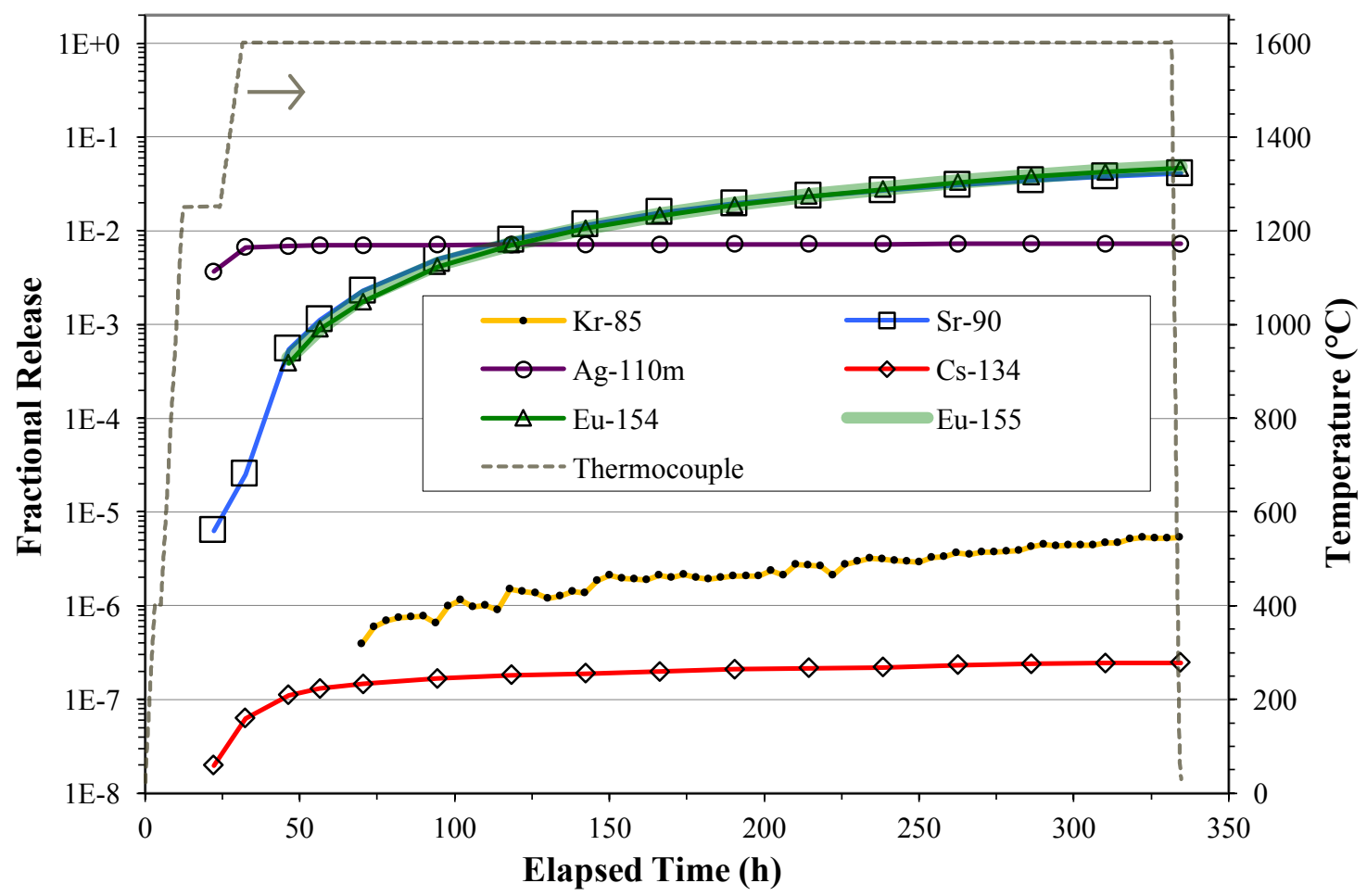

Figure 2. Release of fission products from Compact 2-2-2 during safety testing to $1600^{\circ} \mathrm{C}$. 


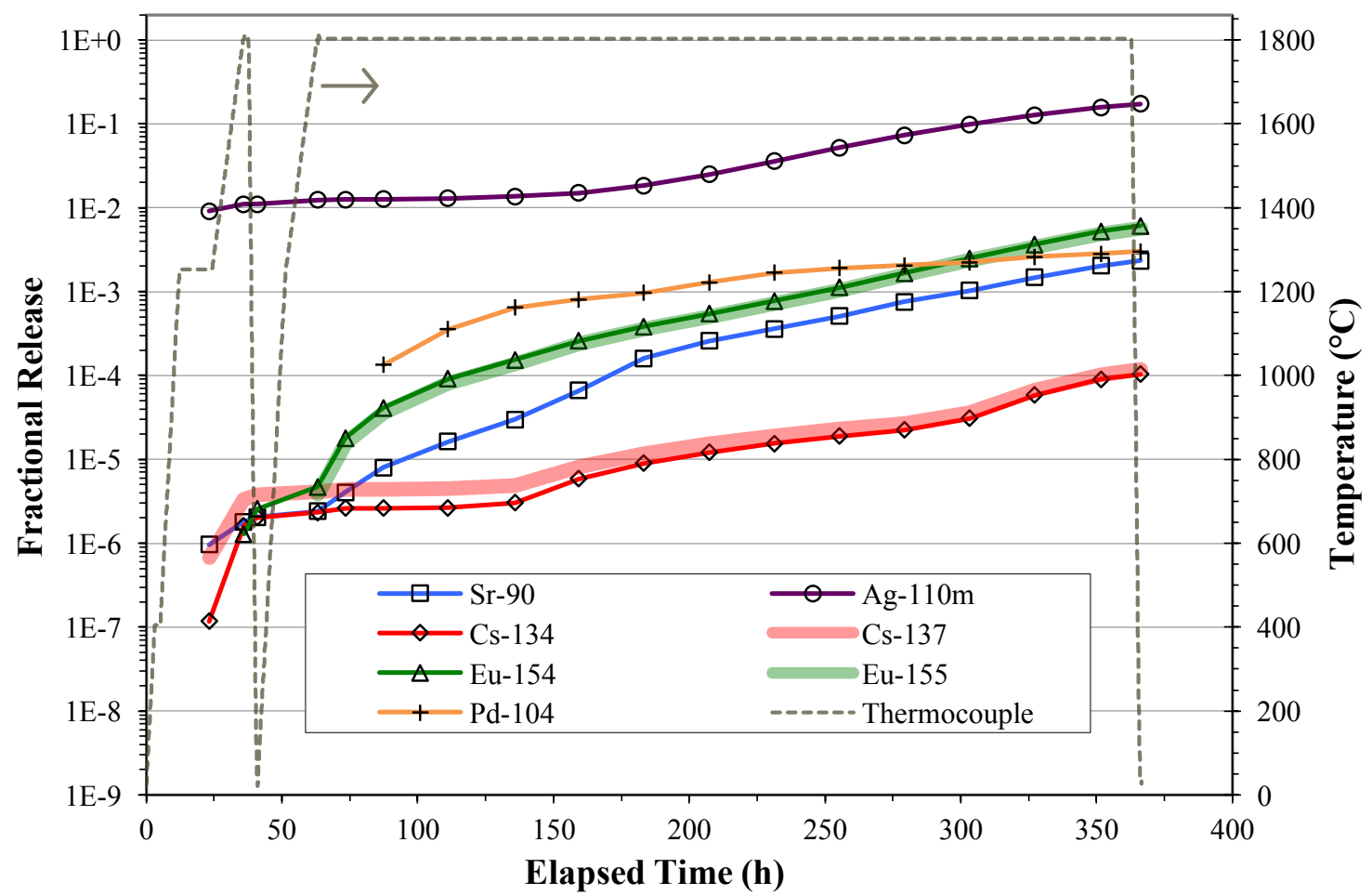

Figure 3. Release of fission products from Compact 5-4-1 during safety testing to $1800^{\circ} \mathrm{C}$.

Table 2. Radioactive isotope distribution on furnace internal components after the Compact 5-2-2 safety test

\begin{tabular}{lcccccc}
\hline Component & ${ }^{90} \mathrm{Sr}$ & ${ }^{110 \mathrm{~m}} \mathrm{Ag}$ & ${ }^{134} \mathrm{Cs}$ & ${ }^{137} \mathrm{Cs}$ & ${ }^{154} \mathrm{Eu}$ & ${ }^{155} \mathrm{Eu}$ \\
\hline Deposition cups & $4.8 \%$ & $32.9 \%$ & $18.6 \%$ & - & $2.1 \%$ & $1.9 \%$ \\
Tantalum parts & $22.3 \%$ & $67.1 \%$ & $81.4 \%$ & - & $9.6 \%$ & $9.1 \%$ \\
Graphite holder & $72.9 \%$ & $\sim 0 \%$ & $\sim 0 \%$ & - & $88.3 \%$ & $89.1 \%$
\end{tabular}

${ }^{137} \mathrm{Cs}$ is not reported for Compact 5-2-2 because it was too low to measure above background contamination.

Table 3. Radioactive isotope distribution on furnace internal components after the Compact 2-2-2 safety test

\begin{tabular}{lcccccc}
\hline Component & ${ }^{90} \mathrm{Sr}$ & ${ }^{110 \mathrm{~m}} \mathrm{Ag}$ & ${ }^{134} \mathrm{Cs}$ & ${ }^{137} \mathrm{Cs}$ & ${ }^{154} \mathrm{Eu}$ & $0.1 \%$ \\
\hline Deposition cups & $0.09 \%$ & $23.8 \%$ & $84.9 \%$ & - & $-155 \mathrm{Eu}$ & $0.1 \%$ \\
Tantalum parts & $45.9 \%$ & $76.2 \%$ & $\sim 0 \%$ & $-4 \%$ & $20.3 \%$ \\
Graphite holder & $54.0 \%$ & $\sim 0 \%$ & $15.1 \%$ & - & $80.5 \%$ & $79.6 \%$
\end{tabular}

${ }^{137} \mathrm{Cs}$ is not reported for Compact 2-2-2 because it was too low to measure above background contamination.

Table 4. Radioactive isotope distribution on furnace internal components after the Compact 5-4-1 safety test

\begin{tabular}{lcccccc}
\hline Component & ${ }^{90} \mathrm{Sr}$ & ${ }^{110 \mathrm{~m}} \mathrm{Ag}$ & ${ }^{134} \mathrm{Cs}$ & ${ }^{137} \mathrm{Cs}$ & ${ }^{154} \mathrm{Eu}$ & ${ }^{155} \mathrm{Eu}$ \\
\hline Deposition cups & $73.9 \%$ & $99.7 \%$ & $98.4 \%$ & $92.7 \%$ & $44.1 \%$ & $38.7 \%$ \\
Tantalum parts & $4.3 \%$ & $0.3 \%$ & $1.5 \%$ & $1.8 \%$ & $16.4 \%$ & $18.0 \%$ \\
Graphite holder & $21.9 \%$ & $\sim 0 \%$ & $\sim 0 \%$ & $5.5 \%$ & $39.5 \%$ & $43.2 \%$ \\
\hline
\end{tabular}


During the AGR-2 UCO Compact 5-2-2 $1600^{\circ} \mathrm{C}$ safety test (Figure 1), there were no indicators for TRISO failure (sudden ${ }^{85} \mathrm{Kr}$ release or cumulative release comparable to a particle inventory) or failed $\mathrm{SiC}$ (sudden Cs release comparable to a few tenths or more of a particle inventory). This is consistent with what was observed in the AGR- $11600^{\circ} \mathrm{C}$ safety tests, where coating failure was rare (3 particles out of $\sim 33,100$ ) [Hunn et al. 2014a]. In the absence of coating failure, AGR-1 safety testing typically showed a $10^{-2}$ to $10^{-1}$ fractional release of silver that occurred as the furnace was heated to the test temperature, a very small fractional release of cesium $\left(<10^{-5}\right.$ and difficult to measure due to hot cell contamination), a $3 \times 10^{-4}$ to $3 \times 10^{-3}$ fractional release of europium, and a $10^{-5}$ to $10^{-3}$ fractional release of strontium [Morris et al. 2014]. Similar results were observed for AGR-2 UCO Compact 5-2-2 (Table 5).

Table 5. Cumulative releases of radioactive isotopes from AGR-2 UCO TRISO safety tests

\begin{tabular}{ccccccc}
\hline \multirow{2}{*}{ Isotope } & \multicolumn{2}{c}{ Compact 5-2-2 } & \multicolumn{2}{c}{ Compact 2-2-2 } & \multicolumn{2}{c}{ Compact 5-4-1 } \\
\cline { 2 - 6 } & $\begin{array}{c}\text { Compact } \\
\text { fraction }\end{array}$ & $\begin{array}{c}\text { Particle } \\
\text { equivalent }\end{array}$ & $\begin{array}{l}\text { Compact } \\
\text { fraction }\end{array}$ & $\begin{array}{c}\text { Particle } \\
\text { equivalent }\end{array}$ & $\begin{array}{c}\text { Compact } \\
\text { fraction }\end{array}$ & $\begin{array}{c}\text { Particle } \\
\text { equivalent }\end{array}$ \\
\hline${ }^{85} \mathrm{Kr}$ & $<7 \times 10^{-7}$ & $<0.002$ & $5.4 \times 10^{-6}$ & 0.017 & $<7 \times 10^{-7}$ & $<0.002$ \\
${ }^{90} \mathrm{Sr}$ & $7.9 \times 10^{-4}$ & 2.5 & $4.1 \times 10^{-2}$ & 130 & $2.3 \times 10^{-3}$ & 7.4 \\
${ }^{110 \mathrm{~m}} \mathrm{Ag}$ & $1.6 \times 10^{-2}$ & 52 & $7.3 \times 10^{-3}$ & 23 & $1.7 \times 10^{-1}$ & 550 \\
${ }^{134} \mathrm{Cs}$ & $5.9 \times 10^{-6}$ & 0.019 & $2.5 \times 10^{-7}$ & 0.00078 & $1.0 \times 10^{-4}$ & 0.33 \\
${ }^{137} \mathrm{Cs}$ & - & - & - & - & $1.2 \times 10^{-4}$ & 0.37 \\
${ }^{154} \mathrm{Eu}$ & $1.1 \times 10^{-3}$ & 3.4 & $4.7 \times 10^{-2}$ & 150 & $6.0 \times 10^{-3}$ & 19 \\
${ }^{155} \mathrm{Eu}$ & $1.1 \times 10^{-3}$ & 3.4 & $4.8 \times 10^{-2}$ & 150 & $5.7 \times 10^{-3}$ & 18 \\
\hline${ }^{137} \mathrm{Cs}$ is not reported for Compacts 5-2-2 and 2-2-2 because it was too low to measure above background contamination.
\end{tabular}

Figure 1 shows that there was a significant release of ${ }^{110 \mathrm{~m}} \mathrm{Ag}$ collected on the first two cups followed by neglible additional release. Figure 4 is a plot of the average fractional release rate for each deposition cup insertion period. The ${ }^{110 \mathrm{~m}} \mathrm{Ag}$ release rate dropped off about two orders of magnitude shortly after the compact reached $1600^{\circ} \mathrm{C}$ and then continued to drop off throughout the rest of the test. Cesium release from Compact 5-2-2 was very low throughout the entire test and difficult to quantify because cesium is a common contamination species in the Irradiated Fuels Examination Laboratory (IFEL) hot cells due to the scope of work performed in those cell over the last five decades. Note that only ${ }^{134} \mathrm{Cs}$ is reported for Compact 5-2-2 because the higher contamination levels for the longer-lived ${ }^{137} \mathrm{Cs}$ prevented meaningful measurement of the very low release of this isotope during the safety test. The release rates of europium and strontium gradually increased during the first part of the Compact 5-2-2 safety test and then essentially leveled out through the remainder of the test (Figure 4).

In the absence of coating failure, the release behavior of silver, europium, and strontium during AGR-1 safety testing was attributed to release of fission products trapped in the compact matrix graphite and outer pyrolytic carbon $(\mathrm{OPyC})$ that had been previously released through intact $\mathrm{SiC}$ during the three-year irradiation [Morris et al. 2014]. This same mechanism is the most likely explanation for the observed release of these elements from AGR-2 Compact 5-2-2. The relatively rapid release of silver can be explained by its low-retention in the carbonaceous OPyC and matrix at elevated temperatures. The relatively slow release of europium and strontium, along with the initial delay in its collection on the deposition cups, can be explained by the fact that these elements diffuse through the OPyC, matrix, and graphite holder at a much slower rate than silver or cesium. Table 2 and Table 3 show that the majority of the europium and strontium released from the compact was still in the graphite holder at the conclusion of the $1600^{\circ} \mathrm{C}$ safety test of Compact 5-2-2. 


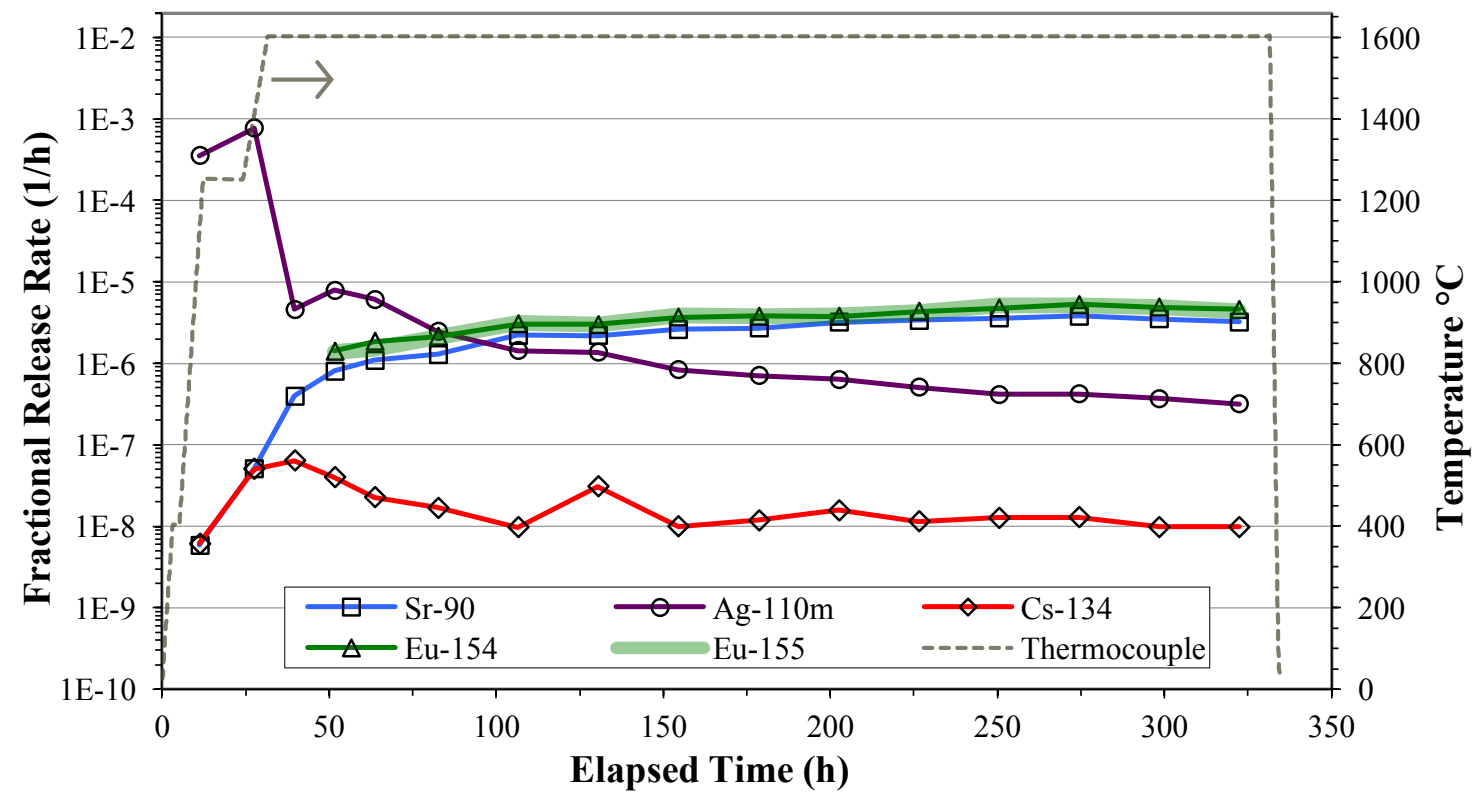

Figure 4. Rate of fission product release from Compact 5-2-2 during safety testing to $1600^{\circ} \mathrm{C}$.

Safety test releases from AGR-2 Compact 2-2-2 (Figure 2 and Figure 5) were similar to Compact 5-2-2 in terms of the total silver release being dominated by early release from the OPyC/matrix and low levels of krypton and cesium release indicating the absence of coating failure. However, europium and strontium release from Compact 2-2-2 was much higher and a small amount of ${ }^{85} \mathrm{Kr}$ was detected in the sweep gas (Table 5). The elevated europium and strontium release can be explained by higher release during irradiation due to the higher irradiation temperature (Table 1). Initial AGR-2 PIE of as-irradiated compacts [Hunn et al. 2016a] indicates there was a dramatically-higher inventory of europium and strontium outside of intact $\mathrm{SiC}$ in the Capsule 2 compacts at the end of irradiation, compared to compacts irradiated at lower temperature in other AGR-2 capsules and in AGR-1. The ${ }^{85} \mathrm{Kr}$ release was too low to have come from a particle with failed TRISO and may be from uranium in the matrix.

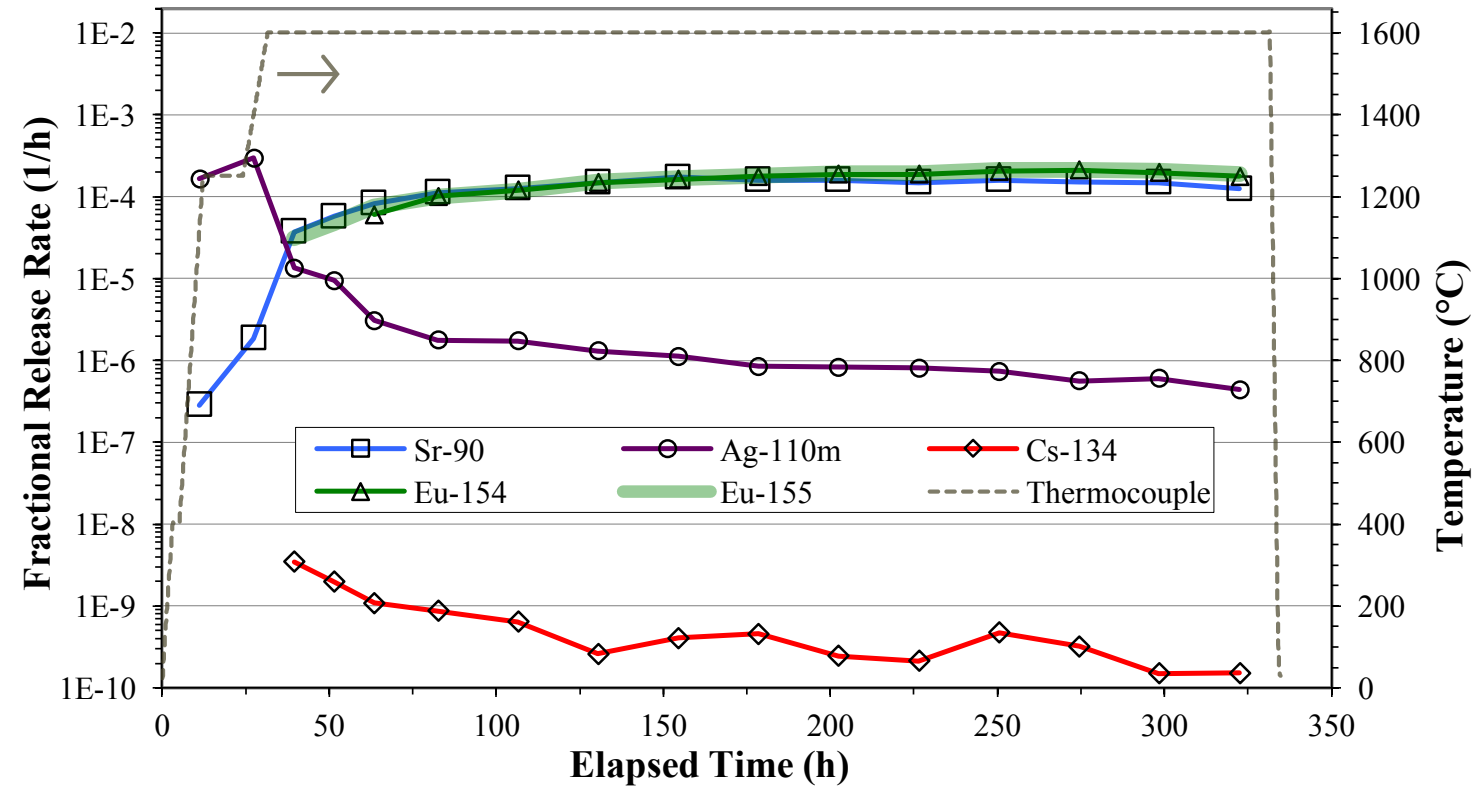

Figure 5. Rate of fission product release from Compact 2-2-2 during safety testing to $1600^{\circ} \mathrm{C}$. 
The $1800^{\circ} \mathrm{C}$ safety test of AGR-2 Compact 5-4-1 (Figure 3) resulted in release behavior different from that observed during the $1600^{\circ} \mathrm{C}$ safety tests of Compacts 5-2-2 and 2-2-2. An initial fractional ${ }^{110 \mathrm{~m}} \mathrm{Ag}$ release of $\sim 1 \%$ was followed by an overall drop in the release rate of almost two orders of magnitude after reaching the test temperature (Figure 6); this was similar to what was observed in the $1600^{\circ} \mathrm{C}$ tests. However, the ${ }^{110 \mathrm{~m}} \mathrm{Ag}$ release rate began to increase after the compact had been at $1800^{\circ} \mathrm{C}$ for about $50 \mathrm{~h}$, and the rate continued to increase for most of the remaining test period. This increase in silver release rate indicates diffusive release through intact $\mathrm{SiC}$ like that seen during $1800^{\circ} \mathrm{C}$ safety testing of AGR-1 Compact 4-4-1 [Hunn et al. 2013a], Compact 4-3-2 [Demkowicz et al. 2015b], and Compact 4-4-2 loose particles [Hunn et al. 2016b], which all had AGR-1 Variant 3 fuel (the AGR-1 variant with SiC produced using an argon diluent, similar to AGR-2 SiC as discussed in Section 1). The cumulative Compact 5-4-1 ${ }^{110 \mathrm{~m}} \mathrm{Ag}$ release was $17 \%$ of the calculated compact inventory (Table 5). Gamma scanning indicated the compact had $\sim 86 \%$ of its calculated inventory at the start of the safety test [Harp, Demkowicz, and Stempien 2014], so the safety test release was actually closer to $20 \%$ of the ${ }^{110 \mathrm{~m}} \mathrm{Ag}$ in the compact at the start of the test. Figure 3 and Figure 6 show that Compact 5-4-1 was heated from room temperature to $1800^{\circ} \mathrm{C}$ twice. This was necessitated by a facility problem with the ventilation fans that required terminating the safety test after $\sim 2 \mathrm{~h}$ at $1800^{\circ} \mathrm{C}$. A brief increase in ${ }^{110 \mathrm{~m}} \mathrm{Ag}$ release rate was observed on the cup that was in the furnace during the second ramp up to $1800^{\circ} \mathrm{C}$. This secondary silver release was observed multiple times during AGR-1 safety testing when compacts were thermally cycled, and a test conducted to explore the effect provided evidence that it may be related to enhanced silver release through intact $\mathrm{SiC}$ between $1075^{\circ} \mathrm{C}$ and $1375^{\circ} \mathrm{C}$ [Hunn et al. 2015b]. Future single-particle heating tests are planned to further study this phenomenon.

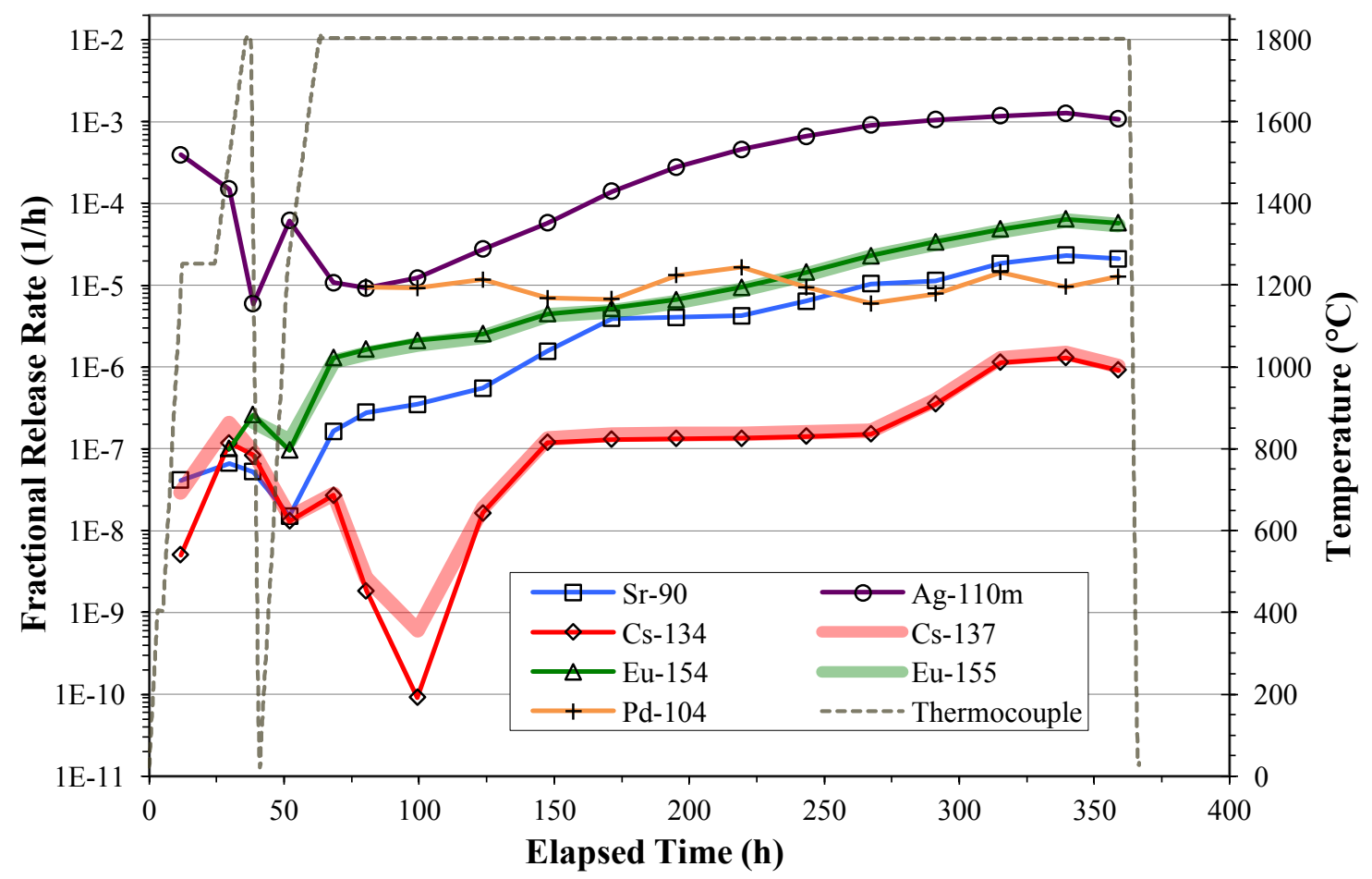

Figure 6. Rate of fission product release from Compact 5-4-1 during safety testing to $1800^{\circ} \mathrm{C}$.

Figure 6 shows that europium and strontium exhibited an increasing release rate throughout most of the $1800^{\circ} \mathrm{C}$ heat soak of Compact 5-4-1. This is in contrast to the near constant release rates observed at $1600^{\circ} \mathrm{C}$ (Figure 4 and Figure 5) and suggests that these elements, like silver, were beginning to diffuse through intact $\mathrm{SiC}$. As for silver, similar europium and strontium release behavior was observed during $1800^{\circ} \mathrm{C}$ AGR-1 safety testing of Variant 3 compacts [Morris et al. 2014]. 
There was also significant palladium release during $1800^{\circ} \mathrm{C}$ safety testing of AGR-2 Compact 5-4-1 (Figure 3). Like silver, palladium is known to diffuse through intact $\mathrm{SiC}$ during irradiation and can reside in the $\mathrm{OPyC} /$ matrix of irradiated compacts at percent-level concentrations [Hunn et al. 2013b, page 10; Demkowicz et al. 2015a, table 11]. However, palladium is not often observed during $1600^{\circ} \mathrm{C}$ safety testing because it is better retained in the carbonaceous materials and low levels of palladium release are difficult to measure in the CCCTF due to the lack of a convenient radioisotope and an ${ }^{40} \mathrm{Ar}^{65} \mathrm{Cu}^{+}$ interference with the more abundant ${ }^{105} \mathrm{Pd}$ stable isotope (the CCCTF deposition cups are coated with copper). During $1800^{\circ} \mathrm{C}$ AGR-1 safety testing [Hunn et al. 2014b, figures 3 and 4], ${ }^{104} \mathrm{Pd}$ was released in measurable concentrations, similar to what was observed during the $1800^{\circ} \mathrm{C}$ safety test of AGR-2 Compact 5-4-1. Given the near constant release rate of palladium shown in Figure 6, it is presumed to be dominated by release from the $\mathrm{OPyC}$ and matrix.

Initial cesium release during the $1800^{\circ} \mathrm{C}$ safety test of AGR-2 Compact 5-4-1 (Figure 3) was very low and nearly equivalent to that observed for the $1600^{\circ} \mathrm{C}$ test of Compact 5-2-2 (Figure 1). However, an increase in the ${ }^{134} \mathrm{Cs}$ release rate from Compact 5-4-1 was observed after about $100 \mathrm{~h}$ at $1800^{\circ} \mathrm{C}$ and again after about $200 \mathrm{~h}$. Similar peaks in the cesium release rate indicated isolated cases of SiC failure during AGR-1 safety testing [Hunn et al. 2014a]. The cumulative ${ }^{134}$ Cs release by the end of the AGR-2 Compact 5-4-1 safety test was equivalent to one-third of one particle inventory (Table 5), which is consistent with release from one or two particles with failed SiC. Particles have been deconsolidated from Compact 5-4-1 and will be surveyed with the ORNL Irradiated Microsphere Gamma Analyzer (IMGA) to attempt to identify (and isolate for microstructural analysis) the one or two low-cesium particles expected to be present based on the cesium release in the CCCTF.

Four AGR-1 compacts were safety tested at $1800^{\circ} \mathrm{C}$ and the number of failed-SiC particles per compact ranged from two to eleven [Hunn et al. 2014a]. With an estimated one or two particles with failed SiC, AGR-2 Compact 5-4-1 exhibited performance at the lower end of the range in failure fraction observed during $1800^{\circ} \mathrm{C}$ safety testing of AGR-1 fuel. The AGR-2 UCO fuel particles experienced less IPyC cracking during irradiation [Hunn et al. 2016a; Rice et al. 2016]. IPyC cracking was a key precursor to $\mathrm{SiC}$ failure in AGR-1 particles [Hunn et al. 2014a], and the reduced prevalence of IPyC cracking in the AGR-2 UCO fuel may have been a factor in the low $\mathrm{SiC}$ failure fraction during the $1800^{\circ} \mathrm{C}$ safety test of AGR-2 Compact 5-4-1.

\section{CONCLUSION}

Safety testing at $1600^{\circ} \mathrm{C}$ was completed on AGR-2 UCO Compacts 5-2-2 and 2-2-2 and at $1800^{\circ} \mathrm{C}$ on AGR-2 UCO Compact 5-4-1. Overall fission product release behavior was similar to that observed for AGR-1 UCO compacts [Morris et al. 2014; Demkowicz et al. 2015a]. The measured fission product release at $1600^{\circ} \mathrm{C}$ appeared to be dominated by release of radioisotopes previously released under irradiation and subsequently retained in the carbonaceous matrix and OPyC until the compacts were heated above the irradiation temperature. No release indicative of coating layer failure was observed at $1600^{\circ} \mathrm{C}$, either full TRISO failure or just $\mathrm{SiC}$ failure, and in the absence of $\mathrm{SiC}$ failure, the measured cesium releases were very low (near the limit of detection). Release of europium and strontium from AGR-2 UCO Compact 2-2-2 was very high (4-5\%) but was still consistent with release from the matrix and $\mathrm{OPyC}$, as the higher Capsule 2 irradiation temperatures resulted in releases at these levels.

Particle failure in Compact 5-4-1 at $1800^{\circ} \mathrm{C}$ was relatively minor compared to AGR-1 safety tests conducted at this temperature. Further PIE will be used to enumerate the actual number of failed-SiC particles, but safety test results suggest only one or two particles experienced $\mathrm{SiC}$ failure. At $1800^{\circ} \mathrm{C}$, the time-dependent fission product release of silver, europium, and strontium indicated measurable release was occurring through intact SiC layers. This behavior was consistent with AGR-1 safety testing of compacts with fine-grain $\mathrm{SiC}$ deposited using an argon diluent to enhance renucleation. This apparent 
diffusive release was not observed from AGR-1 compacts with larger grain structure (AGR-1 Baseline and Variant 1) and it has been suggested that the different behavior may be related to the grain boundary character distribution [Gerczak et al. 2016].

Post-safety test PIE of AGR-2 UCO Compacts 5-2-2, 2-2-2, and 5-4-1 will be presented in a future report. This will include results of the deconsolidation leach-burn-leach (DLBL) analysis for exposed fission products, results from short-counting time IMGA surveys performed on all the recovered TRISO particles, results from long-counting time IMGA measurements performed on specially-selected particles that exhibited significant cesium release or other unusual radioisotopic release, and similar IMGA measurements performed on 40-60 randomly-selected particles. Microstructural analysis using x-ray tomography and materialographic methods will be performed to investigate radiation-induced changes in the particles and elucidate the mechanisms responsible for observed fission product release. Much of this work has already been completed on Compacts 5-2-2 and 2-2-2 and partially described in a proceedings paper for the 8th International Topical Meeting on High Temperature Reactor Technology (HTR-2016) [Morris et al. 2016].

\section{REFERENCES}

Baldwin, C.A., J.D. Hunn, R.N. Morris, F.C. Montgomery, C.M. Silva, and P.A. Demkowicz. 2012. "First Elevated Temperature Performance Testing of Coated Particle Fuel Compacts from the AGR-1 Irradiation Experiment." Paper HTR2012-3-027 in Proceedings of the 6th International Topical Meeting on High Temperature Reactor Technology-HTR 2012, Tokyo, Japan, October 28November 1, 2012. Also published in Nucl. Eng. and Design 271: 131-141.

Barnes, C.M. and D.W. Marshall. 2009. FY 2009 Particle Fabrication and Coater Test Report. INL/EXT-09-16545, Revision 0. Idaho Falls, Idaho: Idaho National Laboratory.

Collin, B.P. 2014. AGR-2 Irradiation Test Final As-Run Report. INL/EXT-14-32277, Revision 2. Idaho Falls, Idaho: Idaho National Laboratory.

Demkowicz, P.A. 2013. AGR-2 Post Irradiation Examination Plan. PLN-4616, Revision 0. Idaho Falls, Idaho: Idaho National Laboratory.

Demkowicz, P.A., J.D. Hunn, R.N. Morris, I.J. van Rooyen, T.J. Gerczak, J.M. Harp, and S.A. Ploger. 2015a. AGR-1 Post Irradiation Examination Final Report. INL/EXT-15-36407, Revision 0. Idaho Falls, Idaho: Idaho National Laboratory.

Demkowicz, P.A., E.L. Reber, D.M. Scates, L. Scott, and B.P. Collin. 2015b. "First High Temperature Safety Tests of AGR-1 TRISO Fuel with the Fuel Accident Condition Simulator (FACS) Furnace." $J$. Nucl. Mater. 464: 320-330.

Gerczak, T.J., J.D. Hunn, R.A. Lowden, and T.R. Allen. 2016. "SiC Layer Microstructure in AGR-1 and AGR-2 TRISO Fuel Particles and the Influence of Its Variation on the Effective Diffusion of Key Fission Products." J. Nucl. Mater. 480: 1-14.

Harp, J.M., P.A. Demkowicz, and J.D. Stempien, "Fission Product Inventory and Burnup Evaluation of the AGR-2 Irradiation by Gamma Spectrometry", Paper HTR2016-18593. Proc. 8th International Topical Meeting on High Temperature Reactor Technology (HTR-2016), Las Vegas, Nevada, November 6-10, 2016.

Hawkes, G.L. 2014. AGR-2 Daily As-Run Thermal Analyses. INL/ECAR-2476, Revision 1. Idaho Falls, Idaho: Idaho National Laboratory. 
Hunn, J.D. and R.A. Lowden. 2006. Data Compilation for AGR-1 Variant 3 Coated Particle Composite LEU01-49T. ORNL/TM-2006/022, Revision 0. Oak Ridge, Tennessee: Oak Ridge National Laboratory.

Hunn, J.D. 2010. AGR-2 Fuel Compacts Information Summary: Prepared for the NRC MELCOR Project. ORNL/TM-2010/296, Revision 1. Oak Ridge, Tennessee: Oak Ridge National Laboratory.

Hunn, J.D., F.C. Montgomery, and P.J. Pappano. 2010a. Data Compilation for AGR-2 UCO Variant Compact Lot LEU09-OP2-Z. ORNL/TM-2010/017, Revision 1. Oak Ridge, Tennessee: Oak Ridge National Laboratory.

Hunn, J.D., F.C. Montgomery, and P.J. Pappano. 2010b. Data Compilation for AGR-2 $\mathrm{UO}_{2}$ Compact Lot LEU11-OP2-Z. ORNL/TM-2010/055, Revision 1. Oak Ridge, Tennessee: Oak Ridge National Laboratory.

Hunn, J.D., T.W. Savage, and C.M. Silva. 2010. AGR-2 Fuel Compact Pre-Irradiation Characterization Summary Report. ORNL/TM-2010/226, Revision 0. Oak Ridge, Tennessee: Oak Ridge National Laboratory.

Hunn, J.D., T.W. Savage, and C.M. Silva. 2012. AGR-1 Fuel Compact Pre-Irradiation Characterization Summary Report. ORNL/TM-2012/295, Revision 0. Oak Ridge, Tennessee: Oak Ridge National Laboratory.

Hunn, J.D., R.N. Morris, C.A. Baldwin, F.C. Montgomery, C.M. Silva, and T.J. Gerczak. 2013a. PIE on Three Irradiated AGR-1 Compacts in FY13. ORNL/LTR-2013/291, Revision 0. Oak Ridge, Tennessee: Oak Ridge National Laboratory.

Hunn, J.D., R.N. Morris, C.A. Baldwin, F.C. Montgomery, C.M. Silva, and T.J. Gerczak. 2013b. AGR-1 Irradiated Compact 4-4-2 PIE Report. ORNL/TM-2013/236, Revision 0. Oak Ridge, Tennessee: Oak Ridge National Laboratory.

Hunn, J.D., C.A. Baldwin, T J. Gerczak, F.C. Montgomery, R.N. Morris, C.M. Silva, P.A. Demkowicz, J.M. Harp, S.A. Ploger, I.J. van Rooyen, and K.E. Wright. 2014a. "Detection and Analysis of Particles with Failed SiC in AGR-1 Fuel Compacts." Paper HTR2014-31254 in Proceedings of the HTR 2014, Weihai, China, October 27-31, 2014. Also published in Nucl. Eng. Design 360: 36-46.

Hunn, J.D., R.N. Morris, C.A. Baldwin, F.C. Montgomery, and T.J. Gerczak. 2014b. PIE on Safety Tested AGR-1 Compacts 5-3-3, 5-1-3, and 3-2-3. ORNL/TM-2014/484, Revision 0. Oak Ridge, Tennessee: Oak Ridge National Laboratory.

Hunn, J.D., R.N. Morris, C.A. Baldwin, and F.C. Montgomery. 2015a, Safety-Testing of AGR-2 UO, Compacts 3-3-2 and 3-4-2. ORNL/TM-2015/388, Revision 0. Oak Ridge, Tennessee: Oak Ridge National Laboratory.

Hunn, J.D., R.N. Morris, C.A. Baldwin, F.C. Montgomery, and T.J. Gerczak. 2015b. PIE on SafetyTested AGR-1 Compact 4-2-2. ORNL/TM-2015/033, Revision 0. Oak Ridge, Tennessee: Oak Ridge National Laboratory.

Hunn, J.D., C.A. Baldwin, F.C. Montgomery, T.J. Gerczak, R.N. Morris, G.W. Helmreich, P.A. Demkowicz, J.M. Harp, and J.D. Stempien. 2016a. "Initial Examination of Fuel Compacts and TRISO Particles from the US AGR-2 Irradiation Test." Paper HTR2016-18443. Proc. 8th International Topical Meeting on High Temperature Reactor Technology (HTR-2016), Las Vegas, Nevada, November 6-10, 2016.

Hunn, J.D., T.J. Gerczak, R.N. Morris, C.A. Baldwin, and F.C. Montgomery. 2016b. PIE on SafetyTested Loose Particles from AGR-1 Compact 4-4-2. ORNL/TM-2015/161, Revision 0. Oak Ridge, Tennessee: Oak Ridge National Laboratory. 
Lowden, R.A. 2006. Fabrication of Baseline and Variant Particle Fuel for AGR-1. ORNL/CF-2006/02, Revision 0. Oak Ridge, Tennessee: Oak Ridge National Laboratory.

Morris, R.N., P.A. Demkowicz, J.D. Hunn, C.A. Baldwin, and E.L. Reber. 2014. "Performance of AGR-1 High Temperature Reactor Fuel During Post-Irradiation Heating Tests." Paper HTR2014-31135 in Proceedings of the HTR 2014, Weihai, China, October 27-31, 2014. Also published in Nucl. Eng. Design 360: 24-35.

Morris, R.N., J.D. Hunn, C.A. Baldwin, F.C. Montgomery, T.J. Gerczak, and P.A. Demkowicz. 2016. "Initial Results from Safety Testing of US AGR-2 Irradiation Test Fuel." Paper HTR2016-18574. Proc. 8th International Topical Meeting on High Temperature Reactor Technology (HTR-2016), Las Vegas, Nevada, November 6-10, 2016.

Phillips, J.A., C.M. Barnes, and J.D. Hunn. 2010. "Fabrication and Comparison of Fuels for Advanced Gas Reactor Irradiation Tests." Paper HTR2010-236 in Proceedings of the 5th International Topical Meeting on High Temperature Reactor Technology, HTR 2010, Prague, Czech Republic, October 1820, 2010.

Rice, F.J., J.D. Stempien, and P.A. Demkowicz. 2016. "Ceramography of Irradiated TRISO Fuel from The AGR-2 Experiment." Paper HTR2016-18455. Proc. 8th International Topical Meeting on High Temperature Reactor Technology (HTR-2016), Las Vegas, Nevada, November 6-10, 2016.

Sterbentz, J.W. 2014. JMOCUP As-Run Daily Depletion Calculation for the AGR-2 Experiment in the ATR B-12 Position. ECAR-2066, Revision 2. Idaho Falls, Idaho: Idaho National Laboratory. 